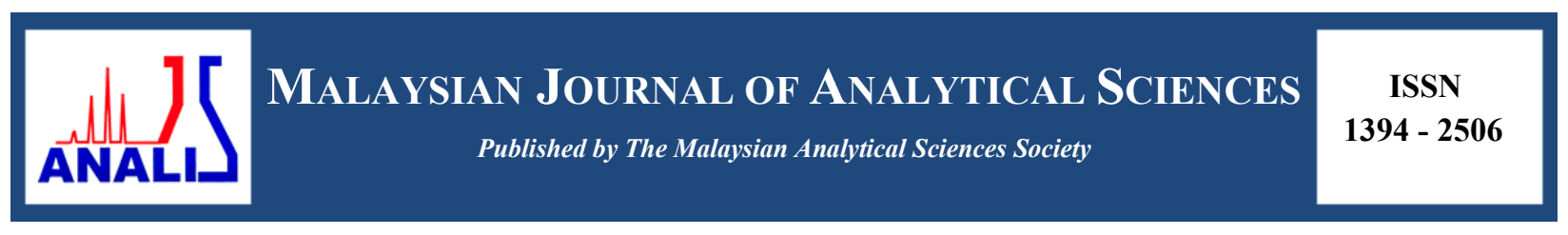

\title{
PHOTOSTABILITY OF PLASTICIZED POLYVINYL CHLORIDE MEMBRANES: A THEORETICAL STUDY
}

\author{
(Kestabilan Foto bagi Membran Plastik Polivinil Klorida: Satu Kajian Teori) \\ Oksana Fizer $^{1}$, Maksym Fizer $^{2 *}$, Yaroslav Studenyak ${ }^{1}$ \\ ${ }^{I}$ Department of Analytical Chemistry \\ ${ }^{2}$ Department of Organic Chemistry \\ Faculty of Chemistry, \\ Uzhhorod National University, 88000 Uzhhorod, Ukraine \\ *Corresponding author: max.fizer@uzhnu.edu.ua
}

Received: 7 March 2017; Accepted: 26 September 2017

\begin{abstract}
The calculation of spectral shifts in the UV-visible region, and the photostability of polyvinyl chloride membranes plasticized with 1-bromonaphthalene, dibutyl phthalate, dioctyl phthalate, o-nitrophenyl octyl ether and tricresyl phosphate, have been systematically investigated using the ZINDO/S method combined with stochastic molecular dynamics with the MMFF94 force field. A Langevin temperature bath was used for the thermostat and the simulation temperature was $298 \mathrm{~K}$ during the entire time of the simulation, which was set to $0.6 \mathrm{~ns}$. These methods were employed to predict the molecular structure of the membranes. The absorption wavelengths and the HOMO and LUMO energies of membrane components are reported. In addition, the photostability of the membranes is discussed in the light of the absorption wavelength. Membranes plasticized with tricresyl phosphate and $o$-nitrophenyl octyl ether show less stability under the action of UV irradiation, as they absorb light with higher energy. Membranes plasticized with butyl and octyl esters of phthalic acid are more stable and show very similar behaviour. A membrane plasticized with 1-bromonaphthalene is likely to be the least sensitive to UV irradiation.
\end{abstract}

Keywords: polyvinyl chloride, membrane, molecular dynamics, excited state, photostability

\begin{abstract}
Abstrak
Pengiraan anjakan spektra di dalam kawasan ultralembayung-cahaya nampak dan kestabilan foto bagi membran plastik polivinil klorida bersama 1-bromonaftalena, dibutil ftalat, dioktil ftalat, $o$-nitrofenil oktil eter dan tricresil fosfat telah secara sistematik telah dikaji mengunakan kaedah ZINDO/S gabungan molekul dinamik stokastik bersama medan daya MMFF94. Suhu rendaman Langevin telah diguna untuk termostat dan suhu simulasi ialah $298 \mathrm{~K}$ bagi keseluruhan masa simulasi, iaitu di tetapkan pada 0.6 ns. Kaedah ini dibangunkan untuk meramal struktur molekul membran berkenaan. Panjang gelombang serapan dan tenaga HOMO dan LUMO membran dilapor. Tambahan lagi, kestabilan foto bagi membran di bincang dari aspek panjang gelombang serapan. Membran plastik bersama tricresil fosfat dan $o$-nitrofenil oktil eter menunjukkan kestabilan yang rendah terhadap penyinaran UV sebagaimana ia menyerap cahaya pada tenaga yang tinggi. Membran plastik bersama butil dan oktil ester asid ftalik adalah lebih stabil dan menunjukkan sifat yang sama. Membran plastik bersama 1-bromonaftalena merupakan membran paling kurang sensitif terhadap penyinaran UV.
\end{abstract}

Kata kunci: polivinil klorida, membran, molekul dinamik, keadaan teruja, kestabilan foto

\section{Introduction}

Ion-selective electrodes (ISEs) with plasticized membranes are widely used in analytical chemistry [1, 2]. ISEs can also be used in environmental analysis [3] and in clinical studies [4, 5]. The main advantages of using ISEs are: 
short analysis time, high selectivity, sensitivity, reliability and reproducibility. Moreover, the electrodes in a potentiometer are relatively cheap and not cumbersome, which makes them suitable for use in the field.

Despite all these advantages, some disadvantages are also known, such as the drift in potential and the influence of interference ions [1]. Usually, errors are caused by changes in the membrane's characteristics during the operation of ISEs. The composition, homogeneity and lifetime of a membrane can change due to the leaching of the membrane's components, such as plasticizers or ionophores. Furthermore, degradation of polymeric compounds can be caused by ultraviolet irradiation. Near-UV radiation may be harmful to the plastics and plasticized plastic films [6-8]. The high-energy photons may cause a gradual degradation of the polymer or the plasticizer. Therefore, it is critical to identify the potential resistance properties of a membrane's materials, and to search for molecules that can withstand longer UV exposure. Even a small UV fraction may create major damage in the membrane via radical formation triggering photodegradation of the polymeric materials. This degradation causes a deviation in the conductivity of the ion-selective membrane and a deterioration in the membrane's physical and chemical properties. Therefore, from an application point of view, UV spectra and absorption energies must be considered as design parameters for the selection of materials in the construction of ISEs.

Quantum chemical calculation is a widely used method for the investigation of matter, especially in cases when direct physical measurements are not possible or too time-consuming. Computation and prediction of structure [9, $10]$, properties [11] and reactivity $[12,13]$ can readily be performed using various methods. The configuration interaction $(\mathrm{CI})$ method is widely employed for the calculation of electronic spectra and photostability $[14,15]$.

In this work, we attempt to obtain a new insight into the photostability of five plasticized polymeric membranes. As model objects, we use polyvinyl chloride membranes plasticized with 1-bromonaphthalene (aBN), dibutyl phthalate (DBP), bis(2-ethylhexyl) phthalate also known as dioctyl phthalate (DOP), o-nitrophenyl octyl ether (NPOE) and tricresyl phosphate (TCP) [16, 17]. The absorption spectra obtained in this work will provide a valuable data set for other computational studies, and we will also use the data set as a basis for future experimental investigations.

\section{Computational details}

\section{Materials and Methods}

The simulations of the five systems were performed using stochastic molecular dynamics (MD) [18] with the MMFF94 force field [19]. The stochastic integrator uses a type of Langevin temperature bath for the thermostat, and the simulation temperature was $298 \mathrm{~K}$. The total simulation time for each system was $600 \mathrm{ps}$, with $100 \mathrm{ps}$ for equilibration and $500 \mathrm{ps}$ as the sampling time. Snapshots were generated for each $10 \mathrm{ps}$ period. The relaxation trajectory was obtained, with 50 snapshots for each system.

Using the snapshot geometries as input, the UV-Vis spectra of the five systems were calculated using the ZINDO/S method with the inclusion of all valence electrons [20]. The CI method in combination with the semi-empirical Hamiltonian enables the calculation of the absorption spectra of large organic systems. In the case of each membrane, we calculated a different number of first excited states, in such a way as to accurately describe the wavelength region above $200 \mathrm{~nm}$. The average UV-Vis spectrum was obtained by overlapping all the spectra computed separately for each snapshot.

MD simulations were performed with the TINKER 7.1 package [21]. ZINDO/S calculations were performed with the program ORCA 3.0.3 [22]. The automatic computations for a group of snapshots were realized through the batch script. The Gabedit 2.4.9 program [23] was used to perform overlapping and visualization of the specified range of UV-Vis spectra. A VMD package [24] was used for calculation of the radial distribution function (RDF). Visualization of molecules and molecular orbitals was performed using the Jmol program [25].

\section{Molecular dynamics simulation of modelled systems}

\section{Results and Discussion}

Computations of PVC membrane parameters were performed on small systems that in our opinion can describe membranes in general reasonably well. Each simulated system (Table 1) was a small cluster of two molecules of plasticizer and one molecule of PVC polymer. This composition allows consideration of not only the polymer- 
plasticizer interaction but also the interaction between plasticizer molecules. The PVC polymer was modelled as a linear molecule consisting of PVC monomers, $-\mathrm{CH}_{2}-\mathrm{CHCl}$-, and terminal $\mathrm{H}$ atoms. The size of the PVC molecule was different in each system to maintain the membranes' composition ratios of PVC to plasticizer at approximately $1: 1$.

Table 1. Simulated systems and their fundamental properties

\begin{tabular}{llclclc}
\hline$\#$ & $\begin{array}{l}\text { Number of } \\
\text {-CH }\end{array}$-CHCl- & $\begin{array}{c}\text { Plasticizer:PVC } \\
\text { Ratio (\%) }\end{array}$ & Composition & Atoms & Formula & $\begin{array}{c}\text { Weight } \\
\text { (g/mol) }\end{array}$ \\
\hline 1 & 6 & $52.35: 47.65$ & $2 \mathrm{aBN}+\mathrm{PVC}_{6}$ & 74 & $\mathrm{C}_{32} \mathrm{H}_{34} \mathrm{Br}_{2} \mathrm{Cl}_{6}$ & 791.138 \\
2 & 8 & $49.93: 50.07$ & $2 \mathrm{DBP}+\mathrm{PVC}_{8}$ & 134 & $\mathrm{C}_{48} \mathrm{H}_{70} \mathrm{Cl}_{8} \mathrm{O}_{8}$ & 1058.689 \\
3 & 12 & $50.95: 49.05$ & $2 \mathrm{DOP}+\mathrm{PVC}_{12}$ & 206 & $\mathrm{C}_{72} \mathrm{H}_{114} \mathrm{Cl}_{12} \mathrm{O}_{8}$ & 1533.107 \\
4 & 8 & $49.34: 50.66$ & $2 \mathrm{NPOE}+\mathrm{PVC}_{8}$ & 131 & $\mathrm{C}_{45} \mathrm{H}_{70} \mathrm{Cl}_{8} \mathrm{~N}_{2} \mathrm{O}_{6}$ & 1018.671 \\
5 & 12 & $49.49: 50.51$ & $2 \mathrm{TCP}+\mathrm{PVC}_{12}$ & 168 & $\mathrm{C}_{66} \mathrm{H}_{80} \mathrm{Cl}_{12} \mathrm{O}_{8} \mathrm{P}_{2}$ & 1488.720 \\
\hline
\end{tabular}

Figure 1 shows the change in total energy at a time during the MD simulation. The chosen integrator provides a reasonable numerical stability. Despite rounding errors and other numerical inaccuracies, the total energies of the systems are relatively well conserved. This shows relative stability and characterizes the chosen method as good enough to obtain reliable geometries. In addition, the thermostat is highly stable, with fluctuations mostly in $\pm 5 \mathrm{~K}$ range, and only in a few steps was the deviation in temperature higher than $20 \mathrm{~K}$. Intermolecular interaction energies, on the other hand, fluctuate considerably for each system during the simulation time. This behaviour can be explained in terms of the size of the system components. There is a huge number of possible conformers for these components, and this can cause huge deviations in intermolecular distances and large fluctuations in this type of interaction. Despite rounding errors and other numerical inaccuracies, the total energy of the system is very well conserved (Figure 1).

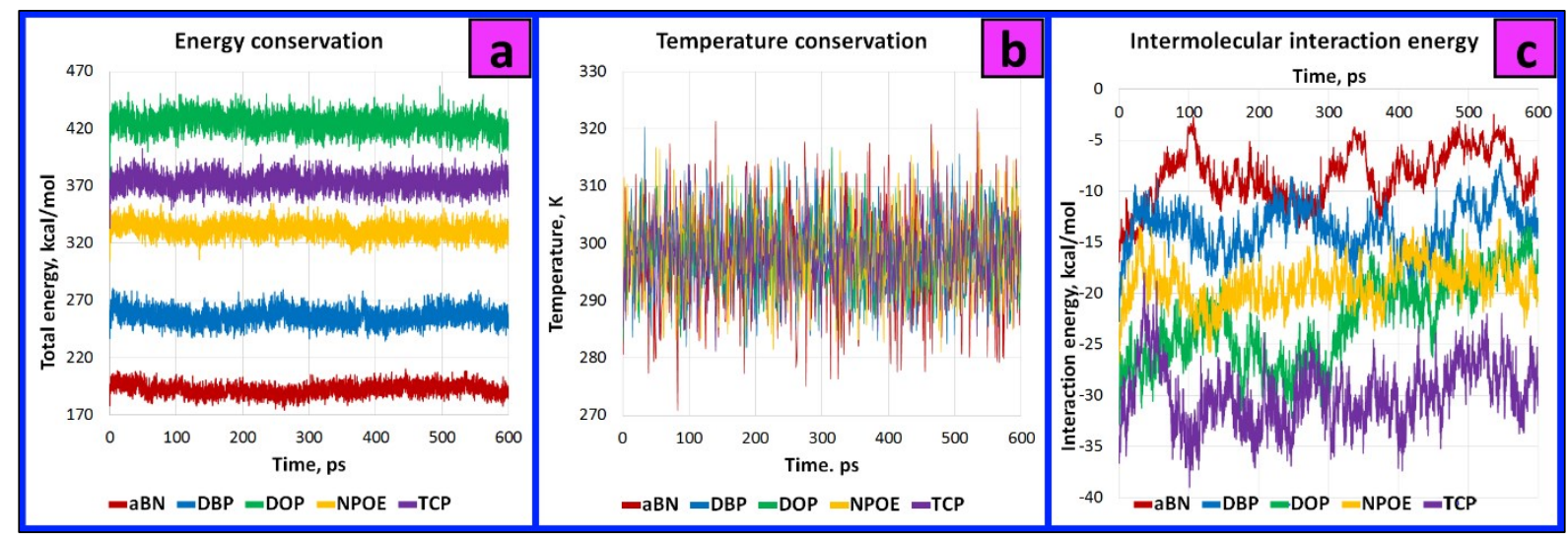

Figure 1. Characteristics of MD simulation (a) conservation of energy, (b) conservation of temperature and (c) intermolecular interaction energy

\section{1-bromonaphthalene-polyvinyl chloride system}

One of the snapshots of the HOMO and LUMO orbitals is shown in Figure 2. The HOMO of the aBN-PVC complex is located along the naphthalene ring and its energy is $-8.00 \mathrm{eV}$. The LUMO of $-0.81 \mathrm{eV}$ is also located in the naphthalene ring. The HOMO-2 and HOMO-1, as well as the LUMO+1 and LUMO+2 of this system are focused on aromatic naphthalene moieties and, among others, also lie in the same energy regions of $-9.24 \mathrm{eV}$, $-8.28 \mathrm{eV},-0.71 \mathrm{eV}$ and $-0.39 \mathrm{eV}$ respectively. This orbital distributions and energies are not unique to this specific 
snapshot but are in general the same for all the generated structures. The RDF is also presented, showing that the average distance between plasticizer molecules and polymer molecules is about 3-15 $\AA$, and the maximal value of the RDF distance during the simulation is 5-7 $\AA$. The distance between 1-bromonaphthalene molecules during the simulation is generally in the range 4-7 $\AA$.
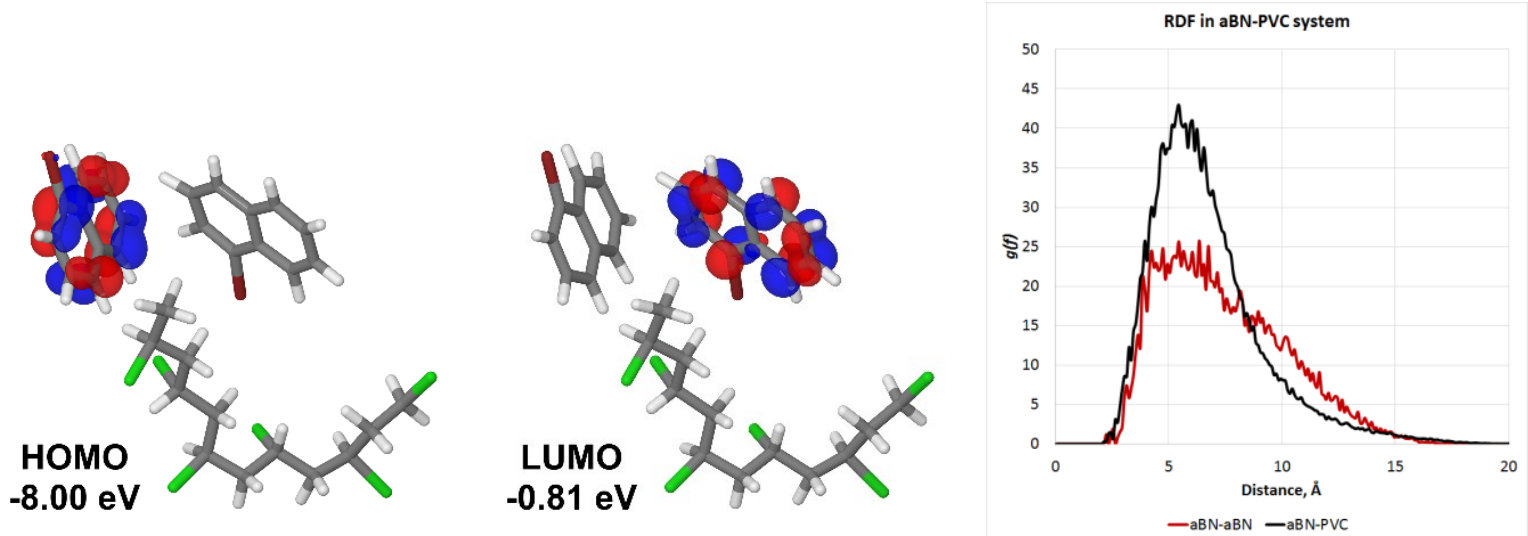

Figure 2. Snapshot geometry with HOMO, LUMO orbitals and RDF for average simulation trajectory of aBN-PVC system

\section{Dibutyl phthalate-polyvinyl chloride system}

The HOMO and LUMO orbitals of the DBP-PVC system are shown in Figure 3. The HOMO is located along the benzene ring of the phthalic acid fragment and its energy is $-9.55 \mathrm{eV}$. The LUMO, with energy $-1.15 \mathrm{eV}$, is also located on the benzene ring. The HOMO-2, HOMO-1, LUMO+1 and LUMO+2 energies of this system are -9.84 $\mathrm{eV},-9.56 \mathrm{eV},-0.96 \mathrm{eV}$ and $-0.25 \mathrm{eV}$ respectively. These are also focused on the aromatic phthalic acid moieties of different molecules of DBP. The distribution of orbitals and energies is characteristic for all generated snapshots of the DBP-PVC system. The RDF shows that the average distance between dibutyl phthalate molecules and polyvinyl chloride is in the range 3-17 $\AA$, with the maximum RDF distance in the region of 5-7 $\AA$.

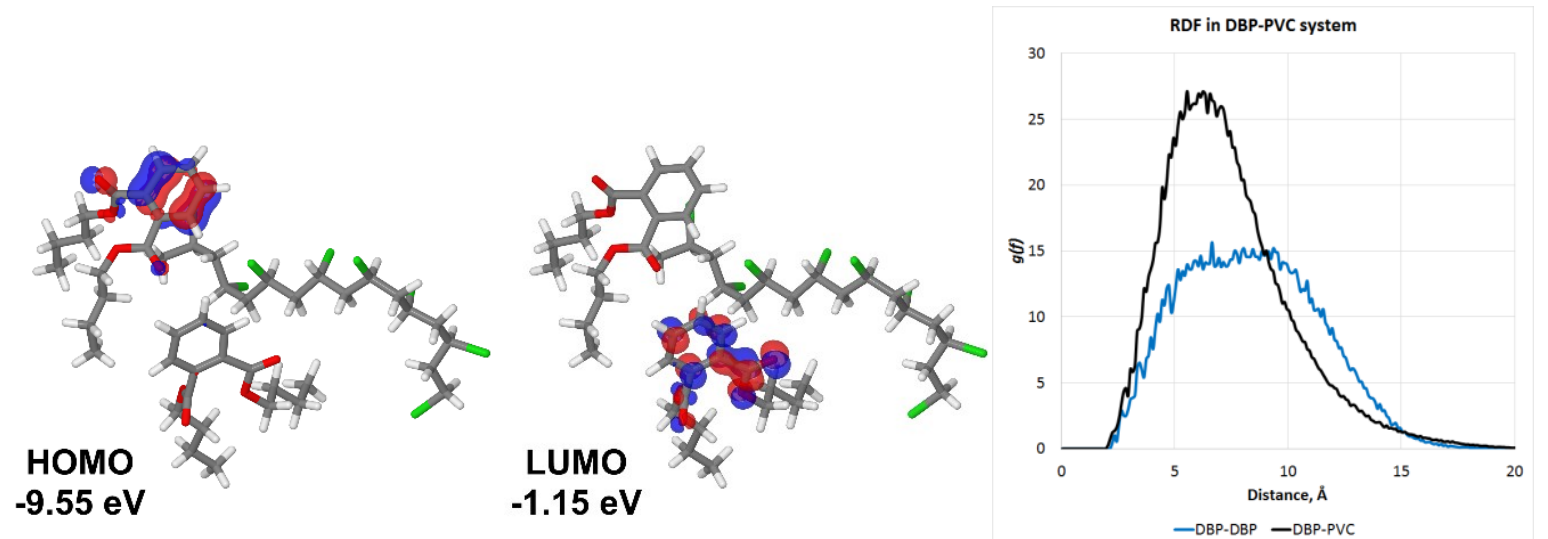

Figure 3. Snapshot geometry with HOMO, LUMO orbitals and RDF for average simulation trajectory of DBPPVC system

\section{Dioctyl phthalate-polyvinyl chloride system}

Figure 4 represents the geometry of the DOP-PVC system. The RDF shows that average distance between dioctyl phthalate molecules and polyvinyl chloride is in the range 3-15 $\AA$, with the maximum RDF distance in the region of 


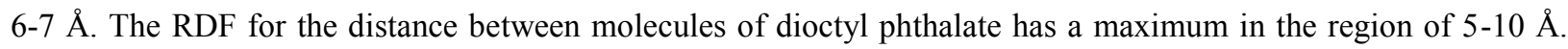
The frontal molecular orbitals can be characterized with the following values of energy: HOMO-2: $-9.73 \mathrm{eV}$, HOMO-1: $-9.59 \mathrm{eV}$, HOMO: $-9.29 \mathrm{eV}$, LUMO: $-1.04 \mathrm{eV}$, LUMO+1: $-0.76 \mathrm{eV}, \mathrm{LUMO}+2 \mathrm{:}-0.32 \mathrm{eV}$. All frontier orbitals of the agglomerate are located along the benzene ring of the phthalic acid fragment, similarly to the DBPPVC system. This can be explained by the similarity in structure and properties of DBP and DOP plasticizers.
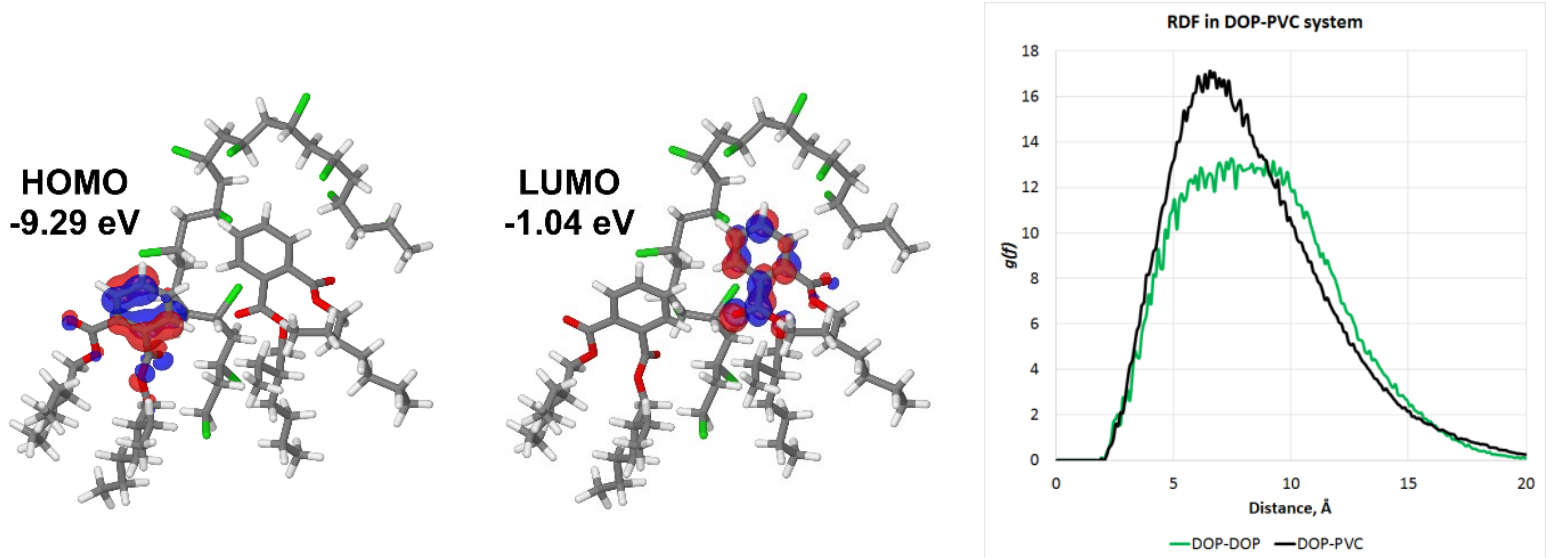

Figure 4. Snapshot geometry with HOMO, LUMO orbitals and RDF for average simulation trajectory of DOPPVC system

\section{Nitrophenyl octyl ether-polyvinyl chloride system}

The geometry of the NPOE-PVC system, with HOMO and LUMO orbitals and RDF distances, is represented in Figure 5. During the MD simulation, the maximum distance distribution between NPOE molecules and PVC was about 5-8 $\AA$ with a total range of RDF distances of 3-15 $\AA$ and a distance between NPOE molecules of around 5-7 $\AA$. The frontal molecular orbitals HOMO-2, HOMO-1, HOMO, LUMO, LUMO+1 and LUMO+2 were characterized by the following values of energy: $-9.89 \mathrm{eV},-9.55 \mathrm{eV},-9.42 \mathrm{eV},-3.10 \mathrm{eV},-2.71 \mathrm{eV}$ and $-0.34 \mathrm{eV}$ respectively. The HOMO is mostly localized on the phenyl ether moiety, whereas the LUMO is in the region of the nitro group. This is in good agreement with general knowledge about the reactivity of organic molecules.
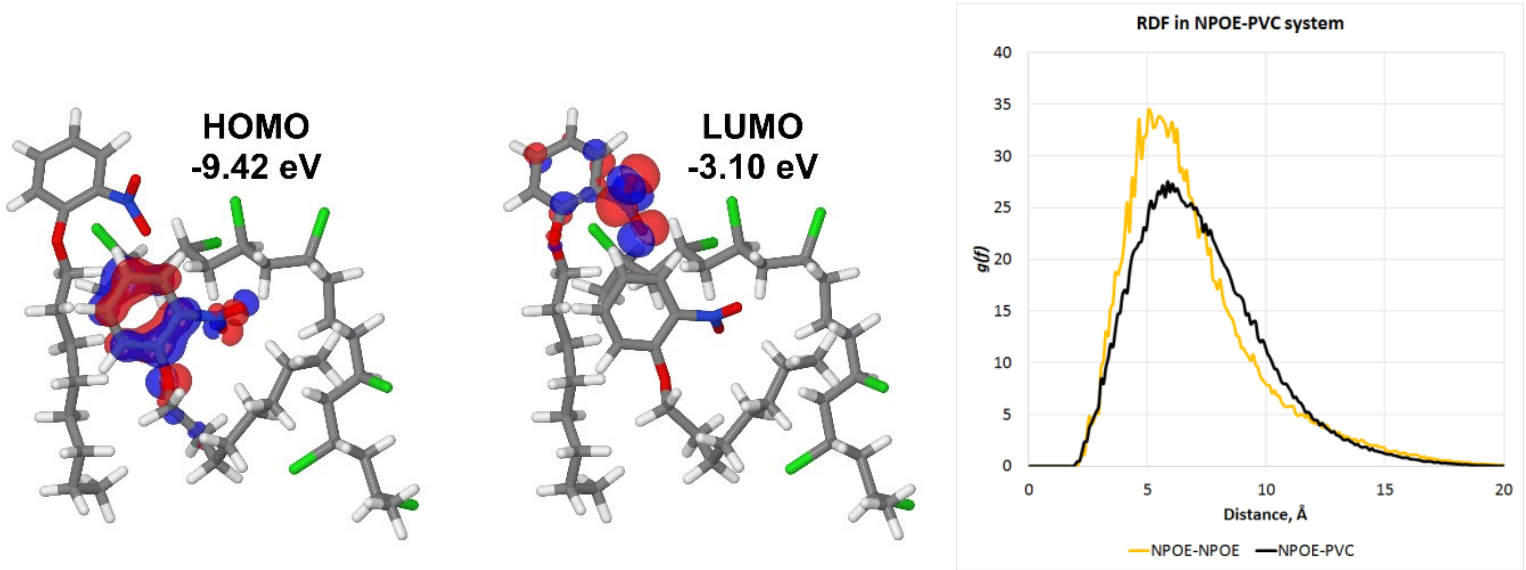

Figure 5. Snapshot geometry with HOMO, LUMO orbitals and RDF for average simulation trajectory of NPOEPVC system 
Fizer et al: PHOTOSTABILITY OF PLASTICIZED POLYVINYL CHLORIDE MEMBRANES: A THEORETICAL STUDY

\section{Tricresyl phosphate-polyvinyl chloride system}

One of the snapshots of the HOMO and LUMO orbitals is shown in Figure 6. The HOMO of the TCP-PVC complex is located along the methyl phenyl rings of the TCP molecule and its energy is $-8.59 \mathrm{eV}$. The LUMO of $0.07 \mathrm{eV}$ is in the region of the $\mathrm{CH}-\mathrm{Cl}$ bond of polyvinyl chloride. The HOMO-2 and HOMO-1 are focused on the aromatic moieties of the plasticizer molecules and lie in the same energy regions of $-8.65 \mathrm{eV}$ and $-8.68 \mathrm{eV}$, whereas the LUMO+1 and LUMO+2 have energy values of $0.156 \mathrm{eV}$ and $0.163 \mathrm{eV}$ respectively and are located on the PVC molecule. This contrasts with all the other systems described here. To understand this behaviour, we analysed the partial atomic charges for each snapshot, and this showed the transport of a small amount of negative charge from TCP to the PVC chain. The average charge of TCP during the simulation is only -0.01 , but this small difference explains the location of unoccupied orbitals and predicts that in the TCP-PVC system the polyvinyl chloride molecule will show more pronounced electrophilic properties. The RDF shows that the average distance between the phosphoric acid ester and the chlorinated polymer is about 3-15 $\AA$, and the maximal value of the RDF distance during the simulation is $4-6 \AA$.
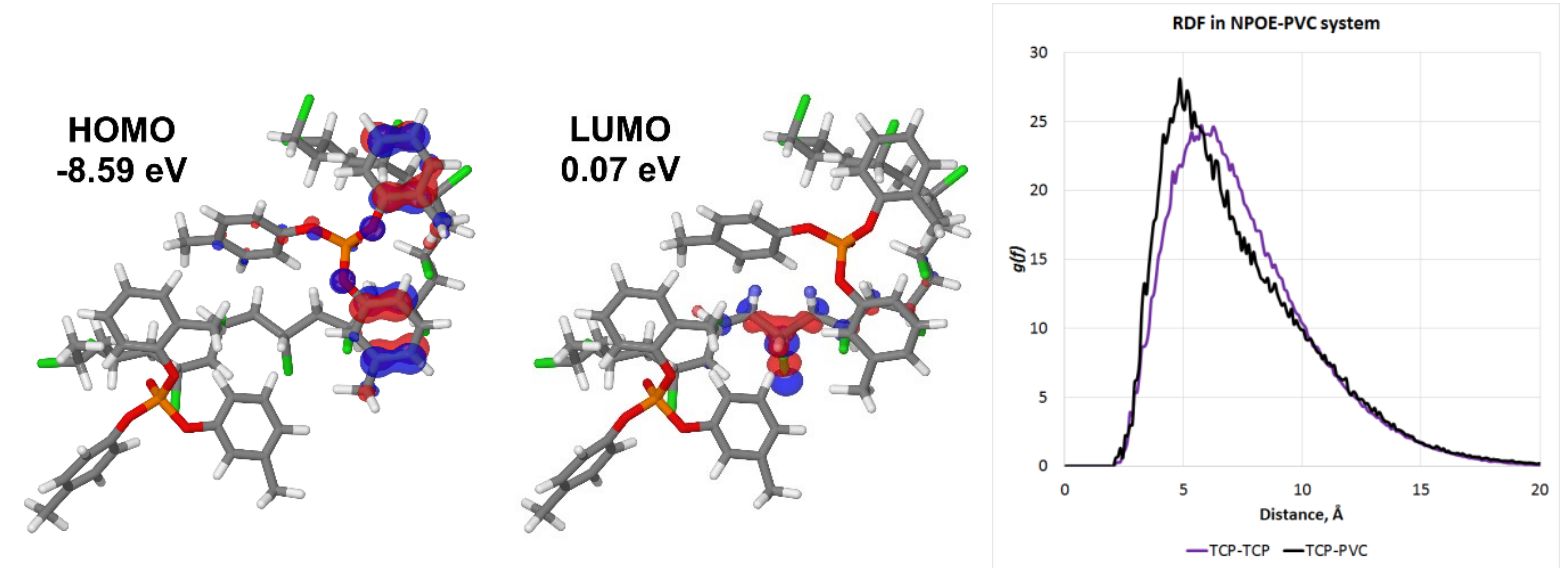

Figure 6. Snapshot geometry with HOMO, LUMO orbitals and RDF for average simulation trajectory of TCP-PVC system

\section{Photochemical stability}

In general, the absorption spectrum of a complex of polyvinyl chloride with a plasticizer molecule containing a phenyl ring is expected to show similarities to a non-substituted benzene molecule. The principal absorption bands in the plasticizer molecules are due to the $\pi \rightarrow \pi^{*}$ transitions in the benzene moieties. However, these benzene-like transitions are not the same in the modelled systems. This difference can be explained by the influence of another condensed phenyl ring in the 1-bromonaphthalene molecule or by the presence of different substituents and conjugation in the other plasticizers considered.

The detailed graph of the comparisons of the UV-Vis spectra computed using the ZINDO/S method is shown in Figure 7. Variations in the absorption spectra were observed for different plasticizer-polyvinyl chloride systems. 


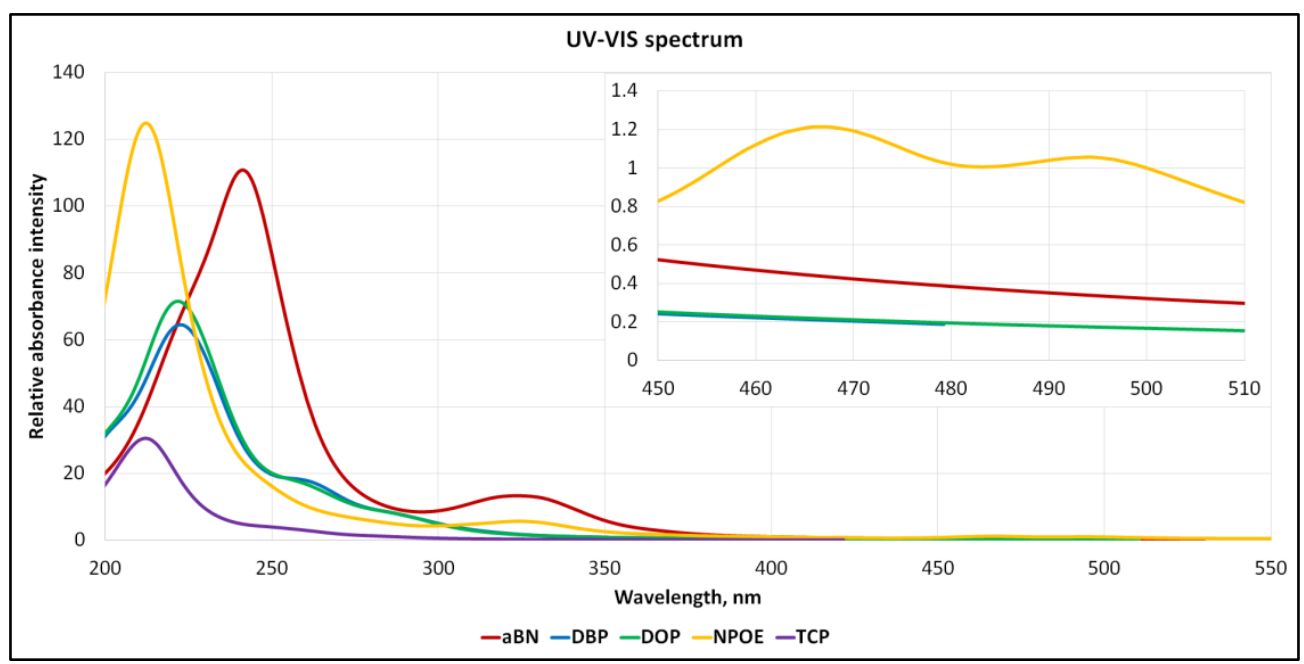

Figure 7. Average UV-Vis spectrum for five systems

\section{1-bromonaphthalene-polyvinyl chloride system}

In the UV region, three strong absorptions at $221.42 \mathrm{~nm}(\lambda 1), 241.44 \mathrm{~nm}(\lambda 2)$ and $323.45 \mathrm{~nm}(\lambda 3)$ were observed. However, no absorption was observed in the visible region. The strongest band appears in the region of $200 \mathrm{~nm}$ to $296.05 \mathrm{~nm}$, with an absorption maximum $\left(\lambda_{\max }\right)$ at $241.44 \mathrm{~nm}(\lambda 2)$. The absorption band at $323.45 \mathrm{~nm}(\lambda 3)$ is in general agreement with UV-Vis spectra of aBN from the NIST database [26]. Experimental data show that the multiple bands in the region of $256-320 \mathrm{~nm}$, and the shift of about $30-50 \mathrm{~nm}$ could be explained by the influence of PVC and by computational error.

\section{Dibutyl phthalate-polyvinyl chloride system}

Figure 7 shows three prominent bands in the UV region with absorption maxima at $222.66 \mathrm{~nm}(\lambda 1), 260.57 \mathrm{~nm}(\lambda 2)$ and $284.78 \mathrm{~nm}(\lambda 3)$ for DBP. The strongest band was observed from $200 \mathrm{~nm}$ to $244.44 \mathrm{~nm}$ with an absorption maximum at $222.66 \mathrm{~nm}(\lambda 1)$. The absorption band at $284.78 \mathrm{~nm}(\lambda 3)$ is in very good agreement with experimental UV-Vis spectra of DBP from the NIST database [27], which show bands at $277 \mathrm{~nm}$ and $286 \mathrm{~nm}$.

\section{Dioctyl phthalate-polyvinyl chloride system}

Three strong absorption bands were observed for DOP in the UV region, with absorption maxima at $226.59 \mathrm{~nm}$ $(\lambda 1), 266.59 \mathrm{~nm}(\lambda 2)$ and $284.94 \mathrm{~nm}(\lambda 3)$ (Figure 7). The strongest band was observed in the region from $200 \mathrm{~nm}$ to $241.88 \mathrm{~nm}$, with an absorption maximum at $226.59 \mathrm{~nm}(\lambda 1)$.

\section{Nitrophenyl octyl ether-polyvinyl chloride system}

The absorption spectrum of the NPOE-PVC system (Figure 7) exhibits one strong and one weak absorption band in the UV region, with absorption maxima at $212.11 \mathrm{~nm}(\lambda 1)$ and $324.16 \mathrm{~nm}(\lambda 2)$ respectively. In addition, there are two very weak absorption bands in the visible region, with absorption maxima at $466.15 \mathrm{~nm}(\lambda 1)$ and $493.88 \mathrm{~nm}$ $(\lambda 2)$. This is in a very good agreement with the fact that NPOE is itself yellow, and absorption in the visible region is very close to the predicted absorption.

\section{Tricresyl phosphate-polyvinyl chloride system}

Two strong absorption bands were observed for the TCP-PVC system in the UV region, with absorption maxima at $212.33 \mathrm{~nm}(\lambda 1)$ and $249.16 \mathrm{~nm}(\lambda 2)$ (Figure 7). One very weak absorption band at $279.08 \mathrm{~nm}(\lambda 3)$ is also present. The strongest band was observed in the region from $200 \mathrm{~nm}$ to $240.08 \mathrm{~nm}$ with an absorption maximum at 212.33 $\mathrm{nm}(\lambda 1)$. 


\section{Conclusion}

Calculations have been carried out on five plasticizer-polyvinyl chloride systems, to study their ultraviolet stability in the light of the shift of absorption wavelength with respect to the nature of the plasticizer. The electronic absorption spectra of plasticized membranes, except in the tricresyl phosphate-polyvinyl chloride system, show the strongest absorption band due to the transitions between the energy states HOMO-1 $\rightarrow$ LUMO and $\mathrm{HOMO} \rightarrow \mathrm{LUMO}+1$, which can be assigned as $\pi \rightarrow \pi^{*}$ transitions. This is due to the presence of two molecules of plasticizer in the systems described, and whereas the HOMO-1 and LUMO correspond to one phenyl/naphthyl ring, the HOMO and LUMO+1 correspond to a transition in another phenyl/naphthyl ring. In the case of the TCP-PVC system, the absorption bands mainly induce transitions of electrons from plasticizer molecules to the polymeric chain.

The principal absorption bands of membranes with TCP and especially with NPOE (considering the much higher relative absorption intensity) show that these membranes are less stable under the action of UV irradiation, as they absorb light with higher energy, causing the bonds to be more easily destroyed. DBP- and DOP-containing systems show very similar behaviour, and they are more stable than the two previously mentioned membranes. A membrane containing 1-bromonaphthalene as a plasticizer is likely to be the least sensitive to UV irradiation.

The methods described show good performance in the study of photostability, and this provides a basis for the future development of computer investigations and quantum chemical simulations in very complex and important objects such as synthetic membrane materials. Furthermore, the presented findings demonstrate that not all placticizers in membranes have the same stability, and therefore testing is needed in each case.

\section{Acknowledgement}

One of the authors (OF) acknowledges the International Visegrad Fund (ID 51700627).

\section{References}

1. Mikhelson, K. N. (2013). Ion-selective electrodes. Springer, Berlin: pp. 1 - 7.

2. Dimeski, G., Badrick T. and St John, A. (2010). Ion selective electrodes (ISEs) and interferences - A review. Clinica Chimica Acta, 411 (5 - 6): 309 - 317.

3. Radu, A., Radu, T., McGraw, C., Dillingham, P., Anastasova-Ivanova, S. and Diamond, D. (2013). Ion selective electrodes in environmental analysis. Journal of Serbian Chemical Society, 78(11): 1729 - 1761.

4. Yan, R., Qiu, Sh., Tong, L. and Qian, Y. (2016). Review of progresses on clinical applications of ion selective electrodes for electrolytic ion tests: from conventional ISEs to graphene-based ISEs. Chemical Speciation \& Bioavailability, 28(1-4): $72-77$.

5. Thakur, V. K. and Thakur, M. K. (2015). Handbook of polymers for pharmaceutical technologies, processing and applications (Vol. 2). Scrivener Publishing LLC, USA: p. 211.

6. Wypych, G. (2015). PVC degradation and stabilization. $3^{\text {rd }}$ Edition. ChemTec Publishing, Toronto: pp. $167-$ 203.

7. Al Ani K. E. and Ramadhan, A. E. (2010). Plasticization effect on the photodegradation of poly (4chlorostyrene) and poly(4-bromostyrene) films. Materials Sciences and Applications, 1 (6): 358 - 368.

8. Ramadhan, A. E. (2015). Effects of added phthalate plasticizers on photodegradation of irradiated poly $(\alpha-$ methylstyrene) films. Journal of Polymer Engineering, 35(2): 159 - 167.

9. Hassan, M. A., Kamarudin, S. K. and Loh, K. S. (2016). Structural study of reduced graphene oxide/polypyrrole composite as methanol sensor in direct methanol fuel cell. Malaysian Journal of Analytical Sciences, 20(4): 965 - 970.

10. Bevziuk, K., Chebotarev, A., Snigur, D., Bazel, Ya., Fizer, M. and Sidey, V. (2017). Spectrophotometric and theoretical studies of the protonation of Allura Red AC and Ponceau 4R. Journal of Molecular Structure, 1144: $216-224$.

11. Arifin, K., Daud, W. R. W. and Kassim, M. B. (2016). Molecular and electronic structures of a new rutheniumtungsten bimetallic complex using density functional theory calculations. Malaysian Journal of Analytical Sciences, 20(4): 946 - 954. 
12. Fizer, M., Sukharev, S., Slivka, M., Mariychuk, R. and Lendel, V. (2016). Preparation of bisthiourea and 5 Amino-4-benzoyl-1,2,4-triazol-3-thione complexes of copper(II), nickel and zinc and their biological evolution. Journal of Organometallic Chemistry, 804: 6 - 12.

13. Fizer, M., Sidey, V., Tupys, A., Ostapiuk, Y., Tymoshuk, O. and Bazel, Y. (2017). On the structure of transition metals complexes with the new tridentate dye of thiazole series: Theoretical and experimental studies. Journal of Molecular Structure, 1149: 669 - 682.

14. Praveen, P. L. and Ojha, D. P. (2012). Effect of substituents on electronic spectral shifts and phase stability of liquid crystalline biphenylcyclohexane molecules - A theoretical approach. Molecular Crystals and Liquid Crystals, 557(1): $206-216$.

15. Praveen, P. L. and Ojha, D. P. (2014). Effect of molecular interactions and end chain length on ultraviolet absorption behavior and photo stability of alkoxycinnamic acids: Theoretical models of liquid crystal. Journal of Molecular Liquids, 197: 106 - 113.

16. Fizer, O. I. and Studenyak, Y. I. (2014). The behavior of PVC-modified membrane sensors in surfactants solutions. Scientific Bulletin of the Uzhgorod University. Series Chemistry, 31(1): 43 - 48.

17. Fizer, O. I. and Studenyak, Y. I. (2015). Potentiometric titration of anionic surfactants in household object. Naukovij visnik Užgorods 'kogo universitetu. Seriâ Himiâ, 34(2): 55 - 58.

18. Attard, P. (2002). Stochastic molecular dynamics: A combined Monte Carlo and molecular dynamics technique for isothermal simulations. Journal of Chemical Physics, 116(22): 9616 - 9619.

19. Halgren, T. A. (1996). Merck molecular force field. I. Basis, form, scope, parameterization, and performance of MMFF94. Journal of Computational Chemistry, 17 (5 - 6): 490 - 519.

20. Kotzian, M., Rösch, N. and Zerner, M. C. (1992). Intermediate neglect of differential overlap spectroscopic studies on lanthanide complexes. Theoretica Chimica Acta, 81(4): $201-222$.

21. Ren, P. and Ponder, J. W. (2003). Polarizable atomic multipole water model for molecular mechanics simulation. The Journal of Physical Chemistry B, 107(24): 5933 - 5947.

22. Neese, F. (2012). The ORCA program system. Wiley Interdisciplinary Reviews: Computational Molecular Science, 2(1): $73-78$.

23. Allouche, A. R. (2011). Gabedit - A graphical user interface for computational chemistry softwares. Journal of Computational Chemistry, 32(1): $174-182$.

24. Humphrey, W., Dalke, A. and Schulten, K. (1996). VMD - visual molecular dynamics. Journal of Molecular Graphics, 14(1): $33-38$.

25. Jmol 14.4.3. (2016). Jmol: An open-source Java viewer for chemical structures in 3D. http://www.jmol.org/.

26. National Institute of Standards and Technology (2017). NIST Chemistry WebBook, SRD 69. http://webbook.nist.gov/cgi/cbook.cgi?ID=C90119\&Units=SI\&Mask=400\#UV-Vis-Spec. [Access online 28 January 2017].

27. National Institute of Standards and Technology (2017). NIST Chemistry WebBook, SRD 69. http://webbook.nist.gov/cgi/cbook.cgi?ID=C84742\&Mask=400\#UV-Vis-Spec. [Access online 28 January 2017]. 